\title{
Annual Report for \\ Environmental Management Science Program Project Number 87016 Co-Precipitation of Trace Metals in Groundwater and Vadose Zone Calcite: In Situ Containment and Stabilization of Strontium-90 and Other Divalent Metals and Radionuclides at Arid Western DOE Sites
}

Principal Investigator

Robert W. Smith

University of Idaho-Idaho Falls

Idaho Falls, ID 83402

(208) 282-7954

smithbob@uidaho.edu

Donna M. Cosgrove

University of Idaho-Idaho Falls

Idaho Falls, ID 83402

(208) 282-7914

cosgrove@if.uidaho.edu

\section{Investigators:}

Co-Principal Investigators

\author{
Yoshiko Fujita \\ Idaho National Engineering and \\ Environmental Laboratory \\ Idaho Falls, ID 83415 \\ (208) 526-1242 \\ fujiy@inel.gov
}

\section{Other Senior Contributors:}

F. "Rick" S. Colwell

Idaho National Engineering and

Environmental Laboratory

Idaho Falls, ID 83415

(208) 526-0097

fxc@inel.gov

\author{
F. Grant Ferris \\ University of Toronto \\ Toronto, Ontario \\ Canada M5S 3B1 \\ (416) 978-0526 \\ ferris@geology.utotonto.ca
}

\section{Research Objectives}

Radionuclide and metal contaminants such as ${ }^{90} \mathrm{Sr}$ are present beneath U.S. Department of Energy (DOE) lands in both the groundwater (e.g., 100-N area at Hanford, WA) and vadose zone (e.g., Idaho Nuclear Technology and Engineering Center (INTEC) at the Idaho National Engineering and Environmental Laboratory). In situ containment and stabilization of these contaminants is a cost-effective treatment strategy. However, implementing in situ containment and stabilization approaches requires definition of the mechanisms that control contaminant sequestration. We are investigating the in situ immobilization of radionuclides or contaminant metals (e.g., ${ }^{90} \mathrm{Sr}$ ) by their facilitated co-precipitation with calcium carbonate in groundwater and vadose zone systems. Our facilitated approach, shown schematically in Figure 1, relies upon the hydrolysis of introduced urea to cause the acceleration of calcium carbonate precipitation (and trace metal co-precipitation) by increasing $\mathrm{pH}$ and alkalinity. Subsurface urea hydrolysis is catalyzed by the urease enzyme, which may be either introduced with the urea or produced in situ by ubiquitous subsurface urea hydrolyzing microorganisms. Because the precipitation process tends to be irreversible and many western aquifers are saturated with respect to calcite, the co-precipitated metals and radionuclides will be effectively removed from the aqueous phase over the long-term. Another advantage of the ureolysis approach is that the ammonium ions produced by the reaction can exchange with radionuclides sorbed to subsurface minerals, thereby enhancing the availability of the radionuclides for re-capture in a more stable solid phase (co-precipitation rather than adsorption). Our specific research objectives include

- Elucidation of the mechanisms and rates for the release of sorbed trace metals and their subsequent sequestration by co-precipitation in calcite induced by urea hydrolysis.

- Evaluation at the field scale of the influence of microbial calcite precipitation on the partitioning and retention of strontium and other naturally occurring divalent metals in groundwater.

- Identification of specific microbial characteristics that signify subsurface geochemical conditions conducive to ureolytically-driven calcite precipitation. 


\section{Research Progress and Implications}

The objectives are being accomplished by conducting integrated field and laboratory research evaluating (a) the precipitation rate of calcite in laboratory and in situ (field) experiments; (b) the partitioning of strontium and other metals into carbonate minerals through laboratory experiments and field characterization; and (c) methods to characterize the ureolytic bacterial community in environmental samples. This report summarizes our progress as of June 2004 and represents the first 21 months of a 3 year project. Key results to date include:

- Demonstrating in laboratory and field the linkage between urea hydrolysis and calcite precipitation.

- Observing that $\mathrm{Sr}^{2+}$ is incorporated into calcite precipitated by urea hydrolyzers, with higher distribution coefficients than in abiotic systems.

- Developing and applying molecular methods for characterizing microbial urease activity in groundwater, including a quantitative PCR method for enumerating ureolytic bacteria, and a method for measuring mRNA transcripts of urease genes.

- Planning and initial deployment of static incubation experiments in the Snake River Plain Aquifer in order to recover precipitate and biomass samples on solid substrates.

- Initial characterization of microbial urease activity in sediment and groundwater samples from the Hanford 100-N Springs site.

These results are summarized below.

Demonstrating the linkage between urea hydrolysis and calcite precipitation. Laboratory experiments at the University of Toronto using pure cultures of Bacillus pasteurii, a known urea hydrolyzer, have yielded kinetic expressions that couple the hydrolysis of urea with the precipitation of calcite over a temperature range (10 to $20 \mathrm{C}$ ) relevant to groundwater conditions (Ferris et al. 2004). These results showed a 10 -fold increase in the first-order rate constant for urea hydrolysis over the temperature range investigated. However, no temperature dependence was observed over the range of investigation for the rate constant of the second-order chemical affinity based expression describing calcite precipitation. Calcite precipitation via urea hydrolysis has also been demonstrated in a field setting. In a single-well push pull test conducted by the INEEL and U. Idaho in the Snake River Plain aquifer, the injection of low levels of molasses $(7.5$ ppm) increased the in situ urea hydrolysis rate by a factor of $\sim 250$ (Fujita et al. 2003). Subsequent injection of mmolar levels of urea resulted in the precipitation of calcite.

Observing that Sr is incorporated into calcite precipitated by urea hydrolyzers, with higher distribution coefficients than in abiotic systems. Batch laboratory experiments using $B$. pasteurii at the INEEL yielded distributions coefficients for $\mathrm{Sr}^{2+}$ in calcite that were significantly higher than those obtained for $\left(\mathrm{NH}_{4}\right)_{2} \mathrm{CO}_{3}$ controls (Fujita et al.). Time-of-Flight Secondary Ion Mass Spectrometry and X-ray absorption spectroscopy analyses were both consistent with the presence of $\mathrm{Sr}^{2+}$ in the calcite as a solid solution. Our results indicate that observed differences between the $B$. pasteurii precipitated calcites and calcites precipitated in the control experiments are the result of differences in the precipitation rate (the higher rates engendered by ureolysis result in greater $\mathrm{Sr}$

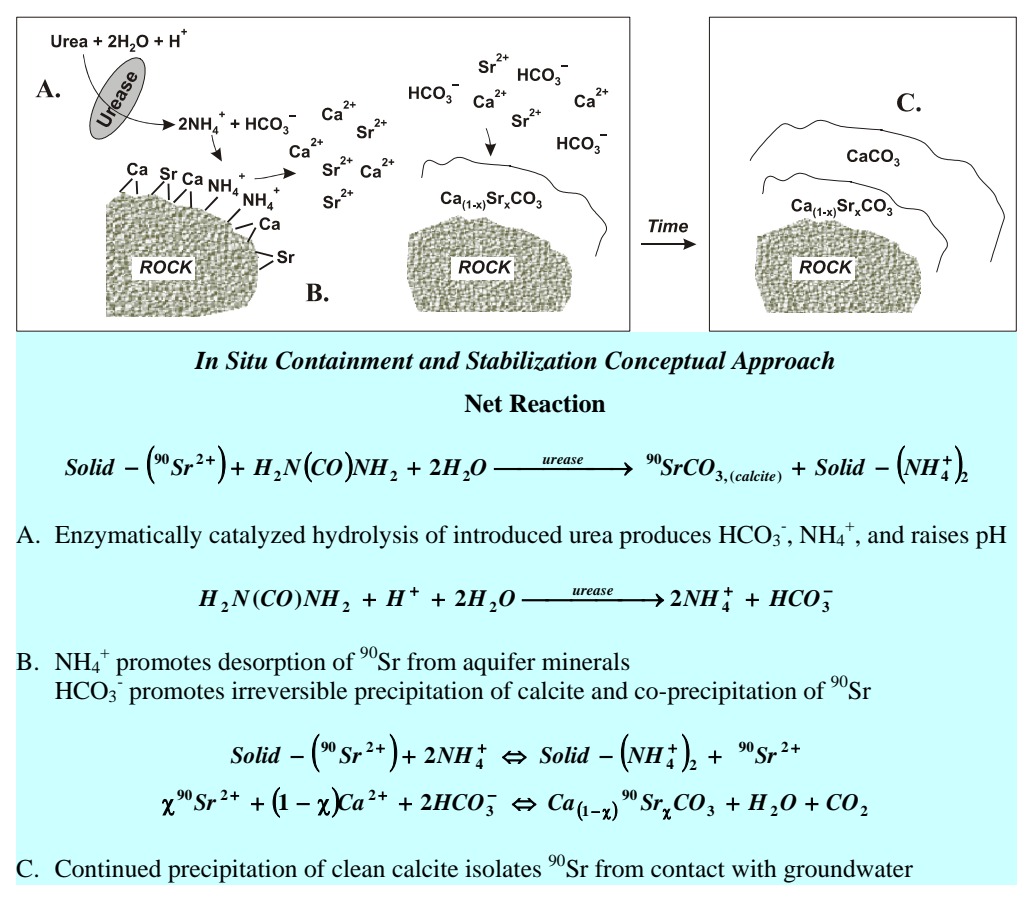

Figure 1. Conceptual approach for in situ containment and stabilization described in this proposal 
partitioning into calcite). Additional experiments that confirm this finding have been completed at the University of Toronto (Mitchell et al.). These results have implications for remediation design; they suggest that stimulating very high rates of ureolysis will be beneficial for maximizing Sr-90 immobilization.

Developing and applying molecular methods for characterizing microbial urease activity in groundwater. Ureasespecific polymerase chain reaction (PCR) primers designed to amplify ureC, a gene that codes for a conserved subunit of the urease enzyme, were developed at the INEEL to detect aquifer microbes with the ability to hydrolyze urea. The primers were designed based on an alignment and phylogenetic analysis of known ureC genes. They were used to determine the presence and diversity (using denaturing gradient gel electrophoresis) of ureolytic bacteria in complex microbial communities collected from the Snake River Plain Aquifer before, during, and after stimulation of the communities by dilute molasses and urea. The results indicated that distinct changes in the microbial communities occurred following the addition of first molasses, then urea. Molasses increased the number of different ureC genes observed, but then urea treatment resulted in a decrease in the number of bands, suggesting that a few key ureolytic species were recruited from a wider community of ureolytic species. A real-time PCR method to quantify ureolytic cell numbers was also developed and applied to the same samples. The results of those analyses indicated that ureolytic cell numbers increased 100-fold following molasses addition. Currently we are also developing methods for quantifying mRNA transcripts of ureC genes by reverse transcriptase real-time PCR, in order to get a more direct measurement of gene expression and confirmation of urease activity. Thus far we have demonstrated success with laboratory cultures; we are currently working on extending the method to environmental samples. The molecular tools are important for demonstrating that microbially catalyzed urea hydrolysis (and associated calcite precipitation) are occurring in situ; such evidence will be critical for both initially assessing the applicability of our method to a contaminated site, and for verifying that the desired biogeochemical process is occurring once remediation activities are underway.

Static incubation experiments in the Snake River Plain Aquifer. The INEEL and U. Idaho have designed a field experiment at a well in Idaho Falls, where we will introduce urea and molasses into a defined zone of the aquifer. Unlike previous experiments, we will introduce the urea and molasses by diffusion, rather than injection. We will incubate retrievable solid substrates (basalt chips and Bio-Sep beads) for deposition of precipitates and biomass. Initial background incubations of the solid substrates have already been performed. Precipitate compositions will be analyzed by tools including laser ablation inductively coupled plasma-mass spectrometry, and biomass will be characterized by real-time PCR and reverse transcriptase real-time PCR for urease genes, and by phospholipid fatty acid for characterization of the total microbial community.

Hanford 100- $N$ site sample characterization. At the INEEL we have received both sediment (core to $\sim 45 \mathrm{ft}$ below land surface) and groundwater from the Hanford 100-N site, and are in the process of characterizing ureolytic activity in the samples. Initial results indicate the presence of ureolytic bacteria in both the solid and water samples, which is promising with respect to the potential applicability of our remediation approach to the $100-\mathrm{N}$ area.

\section{Planned Activities}

During the remaining 15 months of the project we plan to continue research in both the laboratory and the field. In the laboratory, we will continue work on detailed characterization of crystal growth habits and trace metal partitioning during ureolytically driven calcite precipitation in the presence and absence of basalt surfaces, examination of trace metal partitioning in natural and artificial calcites using advanced spectroscopic tools, and development and application of molecular biology tools to evaluate ureolytic activity in environmental samples. We are also initiating studies on ammonium fate and transport in the Snake River Plain Aquifer, including developing capabilities to detect and measure bacterial ammonia oxidation. Work will also continue on the development of a coupled biogeochemical/transport model that can be used for designing field applications. In the field, we will complete our static incubation experiment in Idaho Falls, and we also plan to conduct some push-pull type experiments in perched water at the Vadose Zone Research Park (VZRP) at the INEEL. The VZRP is an analog site for the INTEC area at INEEL, where significant Sr-90 contamination exists in the deep vadose zone. In addition we intend to transfer our results through a workshop that will include regulators and stakeholders as well as technical contributors. 


\section{Information Access}

\section{Publications}

Ferris F.G., V. Phoenix, Y. Fujita, and R.W. Smith. 2004 "Kinetics of calcite precipitation induced by ureolytic bacteria at 10 to $20^{\circ} \mathrm{C}$ in artificial groundwater.” Geochim. Cosmochim. Acta, 68, 1701.

Fujita, Y., Redden, G.D., Ingram, J.C., Cortez, M.M. and R.W. Smith. "Sr incorporation into calcite generated by bacterial ureolysis.” Geochim. Cosmochim. Acta. In press.

Colwell F.S., R.W. Smith, F. G. Ferris, A.-L. Reysenbach, Y. Fujita, T.L. Tyler, J.L. Taylor, A. Banta, M.E. Delwiche, T. McLing, and M.E. Watwood. "Microbially-mediated subsurface calcite precipitation for removal of hazardous divalent cations: Microbial activity, molecular biology, and modeling.” ACS Symposium Series. American Chemical Society. In review.

Mitchell, A. C., Mancini, A., Litwin, Y. and F. G. Ferris. “The Co-Precipitation of Sr into Calcite Precipitates Induced by Bacterial Ureolysis in Artificial Groundwater - Temperature and Kinetic Dependence.” In review.

\section{Presentations}

Petzke, L. M., Tyler, T. L., Shields, M. S., Reed, D. W. and Y. Fujita. “Quantitation of Bacterial Urease Genes in Groundwater by Real-Time PCR.” Poster. American Society for Microbiology general meeting. New Orleans, LA, May 23-27, 2004.

Tyler, T. L., Sheridan, P. P., Watwood, M. E., Fujita, Y. and F. S. Colwell. "PCR-DGGE Analysis of Natural Ureolytic Bacterial Communities During an in situ Remediation Field Test.” Poster. American Society for Microbiology general meeting. New Orleans, LA, May 23-27, 2004.

Fujita, Y., Taylor, J. L., Tyler, T. L., Banta, A. B., Reysenbach, A. L., Delwiche, M. E., McLing, T. L., Colwell, F. S. and R. W. Smith. "Field Experiment to Stimulate Microbial Urease Activity in Groundwater for in situ Calcite Precipitation.” Eos Trans. AGU, 84(46), Fall Meet. Suppl., Abstract B42E-07, 2003.

Smith, R. W. and Y. Fujita. "Biogeochemistry of Strontium-90 Remediation by Microbially Mediated Calcite Precipitation: Potential Application at Hanford, Washington.” Poster presentation at Geological Society of America meeting, Seattle, 2003.

Fujita Y., J.L. Taylor, T.L. Tyler, M.E. Delwiche, T.L. McLing, F.S. Colwell, and R.W. Smith. "Stimulation of groundwater urease activity for in situ calcite precipitation: A field trial." International Symposium on Environmental Biogeochemistry, Aomori, Japan, September 2003.

Smith R.W., Y. Fujita, and F.G. Ferris. “Co-precipitation of trace metals in groundwater and vadose zone calcite: in situ contaminant and stabilization of strontium-90 and other divalent metals and radionuclides at arid western DOE sites.” FY2003 EMSP Principal Investigator Workshop, Richland, WA May 6-7, 2003. http://www.pnl.gov/emsp/fy2003/presentations/smith_bob_87016.pdf

Tyler T.L., P.P. Sheridan, M.E. Watwood, and F. S. Colwell. "Diversity of culturable, ureolytic bacteria isolated from a deep aquifer in a semi-arid high desert region." Poster presentation at American Society for Microbiology national meeting, Washington, DC, May 2003.

Fujita Y., J.C. Ingram, M.M. Cortez, G.D. Redden, and R.W. Smith. "Strontium incorporation into calcite generated by bacterial ureolysis.” Eos Trans. AGU, 83(47), American Geophysical Union Fall Meet. Suppl., Abstract B11B-0728, 2002.

Phoenix V.R. and F.G. Ferris. "Kinetics of calcite precipitation induced by ureolytic bacteria at 10 to $20{ }^{\circ} \mathrm{C}$ in artificial groundwater.” Eos Trans. AGU, 83(47), American Geophysical Union Fall Meet. Suppl., Abstract B11B-0727, 2002 